INTERNATIONAL DESIGN CONFERENCE - DESIGN 2018

https://doi.org/10.21278/idc.2018.0355

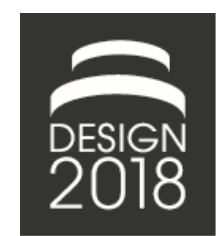

\title{
CONCEPTION OF A CROWDSOURCING TOOL TO SUPPORT INDUSTRIAL DESIGN DECISIONS
}

\author{
M. Wiesner and S. Vajna
}

\begin{abstract}
Industrial Design is still seen as a "soft" factor without big influence within the most product development decisions, because of the low measurability (Kohler, 2003). Therefore it is necessary to develop a tool which enables Industrial Designers to make design preferences empirically measurable. This paper will provide first insights to relevant theories, perspectives and a comprehensive methodology overview for implicit and explicit measuring methods, which will be implemented in future steps in the emerging crowdsourcing approach to support Industrial Design decisions.
\end{abstract}

Keywords: aesthetics, crowdsourcing, decision making, industrial design, implicit measures

\section{Introduction}

In Industrial Design there is a high risk to make the wrong decisions (Kohler, 2003). This is due to a lack of information and the fact that the designer cannot fully predict the customer's preferences (Kohler, 2003). It is not so much the objective attributes of the product, which dominate buying decisions and consumer behaviour, it's the perception and the individual evaluation of a product which influences them the most (Herrmann, 1998; Kohler, 2003). Yamimoto and Lambert showed that the product gestalt has a big influence in customer's evaluation process of a product and in some cases this influence is even greater than the influence of the price (Yamamoto, 1994). Therefore it should be the goal to find a good way to connect decisions in Industrial Design with consumer behaviour and the way people perceive and evaluate objects. There are some studies which show the big influence of Industrial Design in consumer behaviour (Veryzer, 1995; Kohler, 2003; Landwehr, 2008). In contrast to that the Industrial Design is still seen as a "soft" factor without big influence within in the most product development decisions (Kohler, 2003). Product design is not easy to argue, because of the low measurability. Therefore it is necessary to find a way to make design preferences measurable within a product development team. In order to get a better connection to the target groups preferences it's no longer enough to make important design decisions without considering people outside of the product development team and context. The "user-needs gap" (Oehme, 2013) has to be closed. Löbach (1976) defined "empirical aesthetics" as a way to do so as following "Detecting subjective values and aesthetic preferences of groups of people." This is of course an opposite understanding of design to some designers which acquire a normative claim to fulfil an absolute aesthetic value through their aesthetic education (Löbach, 1976; Kohler, 2003). A good approach is to get in contact with a "crowd" of people in their individual context. Luckily the technical possibilities open the way wide for approaches like that. Unfortunately of course not every single designer is able to develop a platform for this or even define the adequate methods to get a view on product design which considers the main dimensions and is empirically based. This paper aims to provide a theoretically foundation of the relevant dimensions 
and perception levels. Based on this, possible methods will be categorised and applied to these dimensions and levels of perception.

\section{Chronologic overview of the different understandings of aesthetic appreciation and industrial design}

The research of aesthetics is based on a long tradition. It is possible to find first publications in the time of Pythagoras between the sixth and fourth century before Christ (Fedrizzi, 2012). The beginning of empirical and experimental research can be found in Fechners "Vorschule der Ästhetik" (1876) (Oehme, 2013). In the following there will be given a short chronological overview of the different understandings of aesthetics and product design throughout this time until now.

Fechner influenced the aesthetics to this day, in particular through his systematic experimental approach (Oehme, 2013). In addition, he postulated various aesthetic principles (minimum stimulating level, aesthetic assistance, simplicity/variety, consistency, clarity and aesthetic association principle) to influence the aesthetic impression. With the last principle (aesthetic association principle) Fechner divides aesthetics into two parts (Zeh, 2010). Aesthetic effects are therefore the result of direct formal (aesthetic) and indirect associative (semantic) factors (Zeh, 2010).

Christian von Ehrenfeld started the development of the Gestalt Theory by the use of term "Gestalt" concept at the end of the 19th century. For him, a gestalt has the characteristics of oversummativity and transposability. Oversummativity means that a gestalt shows attributes that go beyond the properties of the parts(Wirtz, 2014). Transposability means that the form qualities are not tied to a specific entity (Sabar, 2013). Besides these two aspects the law of "Prägnanz" has been defined, which says that we tend to order our experience in a manner that is regular, orderly, symmetrical, and simple. Literally, the German word Prägnanz means conciseness, unambiguity or precision (Sabar, 2013). Based on the principle of gestalt the well-known gestalt laws were established (Metzger, 1967).

The American mathematician Birkhoff developed an aesthetic measure for the mathematical evaluation of the aesthetic content of objects. The so-called Birkhoff measure is composed as a quotient of visual order to complexity (Birkhoff, 1933). He determines the value visual order from the geometric relationships of the gestalt elements to one another.

The Theory of Product Language is one approach to a better understanding of product semantics in design which has been developed at the "Hochschule für Gestaltung" in Offenbach. It starts by distinguishing between two kinds of sensory functions, formal aesthetic and sign functions (Krippendorff, 2006). These are separated in: Indicator functions (Fischer, 1984) and symbol functions (Gros, 1987). Indicator functions make the "practical functions of a product visible and understandable." (Fischer, 1984). Symbol functions pertain to the product's "cultural, social, technological, economic, and ecological meanings." (Gros, 1987). The authors of the theory suggest that symbol functions are responsible for likes or dislikes, as well as for the attribution of such character traits (personality property) as "bourgeois," "modern," and "avant-garde" (Steffen, 2000; Krippendorff, 2006).

The Fluency-Theory assumes that stimuli differ in their mental processing characteristics. There is a number of studies that prove this theory (Tsai and Thomas, 2011). Three types of fluency are to be distinguished: perceptual processing fluency (Reber and Schwarz, 1999) conceptual fluency (semantic meaning), and linguistic fluency (phonological properties of a stimulus). A design is particularly well perceived when simple processing is ensured. A high processing fluency results in a positive affect and thus also has a decisive effect on the affection or rejection of the consumer (Schwemmle, 2016).

Lavie and Tractinsky distinguish in their two-component model of aesthetics classical aesthetics (e.g. clear, symmetric, clean) and expressive aesthetics (e.g. creative, original, fascinating) (Hassenzahl et al., 2003).

Synthesis of the theoretical positions

It can be seen that in design different dimensions have to be considered. There is no doubt that the aesthetic dimension has to be considered. But on top of that it has also be shown that product semantics have to be considered, because they have a big influence on design preferences and the buying intention (Steffen, 2000; Zeh, 2010; Schwemmle, 2016). In this paper product semantics will defined in a way that they also include the social dimensions and hedonic attributes. Therefore two dimensions have to be considered: the aesthetic dimension and the semantic dimension. It is clear that besides design also 
functionality, handleability (Usability), producibility, availability, maintainability, and sustainability of a product have to be considered (Vajna, 2014) but these aspects aren't discussed in this paper. The results of conceptualising a procedure to evaluate design preferences can of course be integrated in such holistic approaches.

\section{Product design frameworks}

As already shown in the introduction, it is very important to design products which fit to the processes of perceiving an object (Hermann, 1998). Product Design Frameworks can help to systemise these processes and differentiate the relevant levels of processing and to get a better view on which variables are influencing design preferences and which reactions they evoke.

\section{Levels of perception in Product Design Frameworks}

Six of these Product Design Frameworks are shown in Figure 1, including different levels of perception and processing in chronological order from left to right.

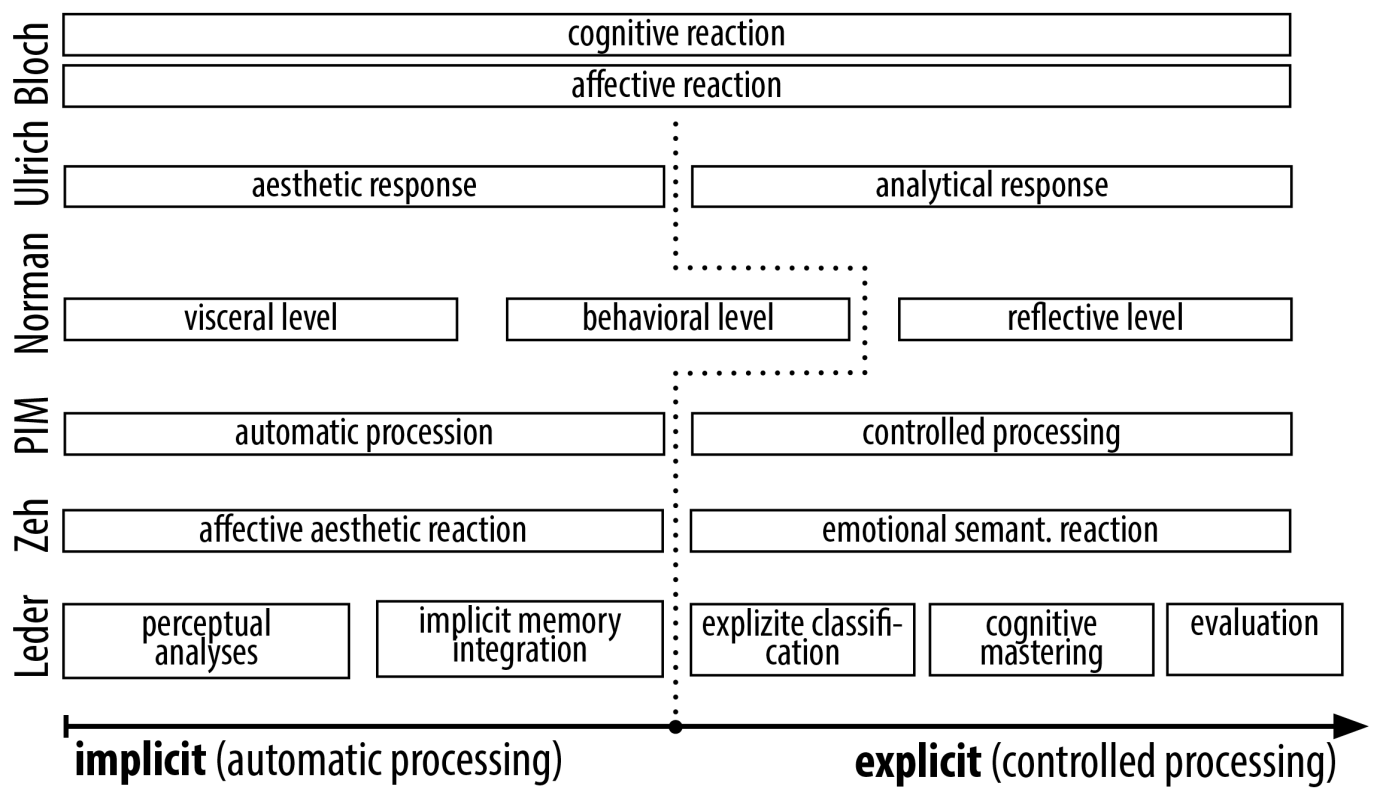

Figure 1. Levels of perception and processing in product design frameworks and their categorisation in implicit (automatic) and explicit (controlled) processing based on (Bloch, 1995; Leder et al., 2004; Norman, 2005; Zeh, 2010; Ulrich, 2011; Graf and Landwehr, 2015)

All these Product Design Frameworks are combined to extract common phases in the perceptual and processing levels, to consider them in design decisions.

\section{Synthesis of the phases of the Product Design Frameworks}

In all these frameworks (except Bloch's model) there is an intended distinction of implicit and explicit processes. The distinction can be made in the sense that implicit processes run completely automatically and without our conscious intervention. Evaluating implicit processes through implicitly measuring methods additionally to the explicit processes with conventional methods seems to be an interesting approach to support design decision because these implicit processes and reactions have a big influence on consumer behaviour (Ulrich, 2011) and too often only explicit processes are considered (Graf and Landwehr 2015). To measure implicit und explicit processing is not yet common in Industrial Design, although in other sciences like psychology this is already common and often necessary (Greenwald et al., 1998). Unfortunately implicit aspects cannot be measured by the tools with which industrial designers are familiar. 


\section{Attributes which influence preferences for product designs}

In Section 3 Product Design Frameworks were considered to extract relevant levels of perception and processing. In this section we want to have a closer look on Product Appearance Attributes.

\subsection{Product appearance attributes}

To get a holistic view what attributes could be interesting, studies of different authors out of different disciplines (and different approaches to extract attributes) were integrated (Table 1).

Table 1. Product appearance attributes

\begin{tabular}{|c|c|c|c|c|}
\hline & Title & Authors & Attributes & $\begin{array}{l}\text { Explicit/ } \\
\text { Implicit }\end{array}$ \\
\hline 1 & $\begin{array}{l}\text { A psychometric investigation of a } \\
\text { scale for the evaluation of the } \\
\text { aesthetic element in consumer } \\
\text { durable goods. }\end{array}$ & Ellis (1993) & $\begin{array}{l}\text { Simplicity, Harmony, Balance, } \\
\text { Dynamics, Unity }\end{array}$ & $\begin{array}{l}\text { explicitly } \\
\text { measured }\end{array}$ \\
\hline 2 & Produktdesign (Product design) & Schwemmle (2016) & Aesthetic, Functional, Symbolic & $\begin{array}{l}\text { explicitly } \\
\text { measured }\end{array}$ \\
\hline 3 & $\begin{array}{l}\text { How Consumers Perceive Product } \\
\text { Appearance }\end{array}$ & $\begin{array}{l}\text { Blijlevens et al. } \\
(2009)\end{array}$ & $\begin{array}{l}\text { Modernity, Simplicity, } \\
\text { Playfulness }\end{array}$ & $\begin{array}{l}\text { explicitly } \\
\text { measured }\end{array}$ \\
\hline 4 & $\begin{array}{l}\text { The Identification of Three } \\
\text { Product } \\
\text { Appearance Attributes }\end{array}$ & $\begin{array}{l}\text { Veryzer et al. } \\
(1998)\end{array}$ & $\begin{array}{l}\text { Visual Attractiveness, } \\
\text { Prototypicality, Unity }\end{array}$ & $\begin{array}{l}\text { explicitly } \\
\text { measured }\end{array}$ \\
\hline 5 & $\begin{array}{l}\text { Towards a unified model of } \\
\text { aesthetic pleasure in design }\end{array}$ & $\begin{array}{l}\text { Berghman, Hekkert } \\
\text { (2017) }\end{array}$ & $\begin{array}{l}\text { Aesthetic appreciation, Typicality, } \\
\text { Novelty, Unity, Variety, } \\
\text { Connectedness, Autonomy }\end{array}$ & $\begin{array}{l}\text { explicitly } \\
\text { measured }\end{array}$ \\
\hline 6 & $\begin{array}{l}\text { Erfolgsfaktor Produktdesign } \\
\text { (Success factor product design) }\end{array}$ & Zeh (2010) & $\begin{array}{l}\text { Simplicity-Complexity, } \\
\text { Familiarity - Novelty, Degree of } \\
\text { personal significance }\end{array}$ & $\begin{array}{l}\text { Implicitly } \\
\text { / explicitly } \\
\text { measured }\end{array}$ \\
\hline 7 & Aesthetics and psychobiology & Berlyne (1971) & $\begin{array}{l}\text { Complexity (r), Instability (r), } \\
\text { Novelty(r), Surprise (r), Conflict } \\
\text { (r) Ambiguity (r) }\end{array}$ & $\begin{array}{l}\text { Implicitly } \\
\text { / explicitly } \\
\text { measured }\end{array}$ \\
\hline 8 & $\begin{array}{l}\text { Zur Bewertung von } \\
\text { Anmutungsqualitäten (Evaluation } \\
\text { of semantic qualities) }\end{array}$ & Frey (1993) & $\begin{array}{l}\text { Value, Time, Peculiarity, } \\
\text { Aesthetics, Atmosphere, Trust, } \\
\text { Superiority }\end{array}$ & $\begin{array}{l}\text { explicitly } \\
\text { measured }\end{array}$ \\
\hline 9 & Product Aesthetics & $\begin{array}{l}\text { Leder and Hekkert } \\
(2008)\end{array}$ & $\begin{array}{l}\text { Balance, Good proportion, } \\
\text { Symmetry, Complexity and } \\
\text { Variety, Unity in Variety, } \\
\text { Conjunctive Ambiguity, } \\
\text { Familiarity and Prototypicality, } \\
\text { Originality, Novelty, } \\
\text { Innovativeness }\end{array}$ & $\begin{array}{l}\text { explicitly } \\
\text { measured }\end{array}$ \\
\hline 10 & $\begin{array}{l}\text { The Thing and I: Understanding } \\
\text { the Relationship Between User and } \\
\text { Product }\end{array}$ & $\begin{array}{l}\text { Hassenzahl et al. } \\
(2003)\end{array}$ & $\begin{array}{l}\text { Hedonic Quality (Stimulation), } \\
\text { Hedonic Quality (Evocation), } \\
\text { Hedonic Quality (Identification), } \\
\text { Attractivity (Aesthetic); Pragmatic } \\
\text { quality }\end{array}$ & $\begin{array}{l}\text { explicitly } \\
\text { measured }\end{array}$ \\
\hline 11 & $\begin{array}{l}\text { Two component model of } \\
\text { aesthetics }\end{array}$ & $\begin{array}{l}\text { Lavie and } \\
\text { Tractinsky (2004) }\end{array}$ & $\begin{array}{l}\text { Classical: clear, symmetric, clean } \\
\text { expressive aesthetics: creative, } \\
\text { original, fascinating }\end{array}$ & $\begin{array}{l}\text { explicitly } \\
\text { measured }\end{array}$ \\
\hline
\end{tabular}


Table 1 shows that most authors use explicit measures to evaluate their attributes. Only Zeh and Berlyne describe implicit measures. Both consider evaluation through sensory acquisition (physiological).

\subsection{Synthesis of the most relevant attributes}

It turns out that there are some attributes which are integrated in most publications for example complexity or prototypicality. Obviously there are also some attributes which are not often considered. It seems reasonable that the ones that haven't been considered often aren't that important for the majority of the included researchers. In Table 2 all attributes are mentioned, which are included at least two times in the different publications. One exception in the selection of the attributes has been made by the attribute playfulness. This one was selected even though it was mentioned once., because of the consumer centred approach that has been made to extract consumer orientated attributes (Blijlevens et al., 2017). Table 2 shows additionally the main dimension which is being considered. The transitions are fluent in some cases. This table shows whether the attribute is a direct indicator for a design preference or is defined as a bipolar classification of a design. For the second property it is not defined which position is the best on the scale and can differ from individual, product and context.

Table 2. Synthesis of the most relevant product appearance attributes

\begin{tabular}{|l|l|l|}
\hline Attributes & Suggested Scale Type & Main Dimension \\
\hline Symmetry / Asymmetry & Bipolar classification scale & Aesthetic dimension \\
\hline Unity / Variety & Bipolar classification scale & Aesthetic dimension \\
\hline Simplicity / Complexity & Bipolar classification scale & Aesthetic dimension \\
\hline Unambiguousness / Ambiguousness & $\begin{array}{l}\text { Bipolar classification scale with } \\
\text { extractable rating }\end{array}$ & Aesthetic dimension \\
\hline Aesthetic Attractiveness & Direct indicator for a design preference & Aesthetic dimension \\
\hline Balance / Instability & Bipolar classification scale & $\begin{array}{l}\text { Aesthetic dimension and } \\
\text { semantic dimension }\end{array}$ \\
\hline Novelty / Prototypicality & Bipolar classification scale & $\begin{array}{l}\text { Aesthetic dimension and } \\
\text { semantic dimension }\end{array}$ \\
\hline Playfulness / Functional & Bipolar classification scale & Semantic dimension \\
\hline Originality / Classic & Bipolar classification scale & Semantic dimension \\
\hline Connectedness / Autonomy & Bipolar classification scale & Semantic dimension \\
\hline Degree of personal significance & Bipolar classification scale & Semantic dimension \\
\hline
\end{tabular}

\subsection{Individual factors and situative factors influencing design preferences}

In some of the frameworks especially in Bloch's model, individual factors and situative factors are being considered (Bloch, 1995). It is supposed to be a valuable additional approach to measure these so called moderating factors to analyse a possible interrelation to design preferences. This interrelation is supposed to be valuable to give an answer to the question which kind of people prefer one product design or another. This additional information is interesting for design decision because of the resulting information about achievable market segments.

A number of consumer research studies have investigated the influence of Individual Tastes and Preferences on design preference. There is even a branch in research of aesthetics (subjectivism) which says that this is the most relevant aspect and that there are no universal principles in design preferences (Landwehr, 2008). Recent publications describe a symbiosis of subjectivism and objectivism as interactionalism (Merleau-Ponty and Edie, 1971; Ingarden, 1985) and postulate that some definable stimulus properties interact with some definable qualities of the observer (Landwehr, 2008). This 
approach will be integrated into the planned design decision tool. Crilly et al. (2004) include in their consideration e.g. age, gender, experience and personality as well as the consumer's self-confidence, social aspirations and personal ideologies. It seems to be an approach to measure these individual factors. There is a possibility to describe personality in the "big" five personality dimensions: neuroticism, openness to experience, agreeableness, and conscientiousness (Digman, 1990). Additionally Zeh (Zeh, 2010) proposes a scale ("Perzeptionstypen") with which different individual types of perception can be measured and classified. This could serve interesting interrelations between the bipolar classification attributes e.g. complexity/simplicity and the optimum stimulation level of an observer (Zeh, 2010).

Most of the situative factors can be understood as restrictions that have to be considered by presenting the product-design to customers. In this category of situative factors we can find the mere exposure effect, which explains the phenomena that presenting preferred or neutral product designs several times the preference increases (Zajonc, 1968). Of course all product designs have to be presented in an identical way. As an example, the effect of isoluminance should be mentioned here. That means that all product design should be illuminated identically. Some situative factors cannot be fulfilled by restrictions in the experimental design, because they are bound to the emotional or cognitive state the subjects are in to. Evaluating these factors seems to be relevant for the planned decision tool, because these factors could explain unexpected results. Noteworthy factors are the involvement, the emotional state and whether the subjects are currently exposed to pain.

\section{Crowdsourcing of design preferences}

Although the earliest formalisation of crowdsourcing may be long time ago, the explicit usage of the term 'crowdsourcing' is generally attributed to being first coined in 2006 by a journalist for Wired magazine (Howe, 2006) as a play on the commonly known term "outsourcing" (Burnap, 2016). In this paper the following definition of Burnap will be used (Burnap, 2016): "The aggregation of input for a given design task from a number of people other than the designer herself, using a systematic aggregation procedure enabled by the reach and scale of the internet and modern computation, with the goal of augmenting the designer's decision-making during the design process." Crowdsourcing can fulfil different roles as shown in Figure 2.

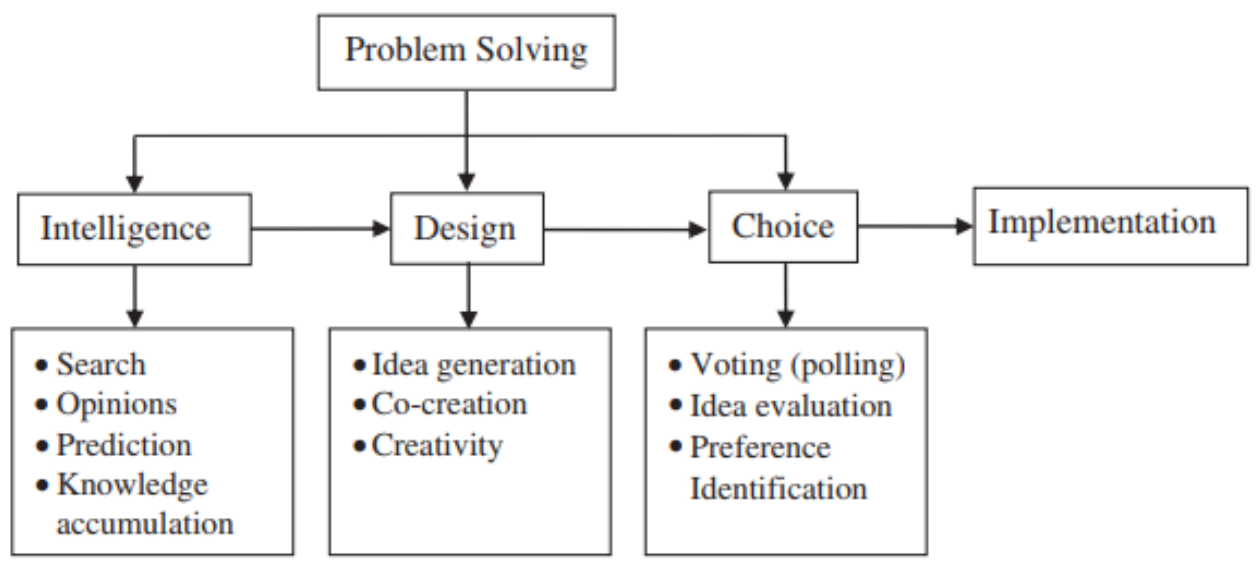

Figure 2. Roles of a crowd in different decision making phases (Chiu et al., 2014)

In this contribution crowdsourcing is used for the preference identification and for evaluating (polling) the attributes shown in Section 4. The need for such a preference identification tool also results from crowdsourced designs. With these co-creation processes a lot of concepts can be found, but the next challenge is to find the best ones. It would be also possible to close the loop through iteration processes between crowdsourcing designs and crowdsourced preference identification (as it has been done for text editing by (Little et al., 2009)). Even a parameter optimization based on co-created designs which is 
optimized through algorithms based on crowd preference identification is possible and is part of own further research (similar research to this was done before, e.g. (Yanagisawa and Fukuda, 2004), in which the methods to measure design preferences can be improved).

\section{Overview of methods to identify design preferences}

There are a lot of possible methods to identify design preferences or to evaluate aesthetics of an object (Greb et al., 2016). As described in Section 3 it is necessary to measure implicit and explicit processing. And as described in Section 2 and 4 it is necessary to evaluate different dimensions, attributes as well as situative and individual factors.

\subsection{Clustering methods based on their type of acquisition}

To get an overview of methods and tools it is possible to cluster them into groups. In a meta-study of the Journal "Empirical Studies of the Art" methods were classified into the following groups: behavioural, computational, content analysis, experiment, interview, observation, physiological, rating and surveys (Greb et al., 2016). These nine groups can be reduced to the following five main groups on the base of their type of acquisition:

- Preference evaluation through sensory acquisition (physiological)

- Preference evaluation through questioning (surveys, and ratings)

- Preference evaluation through observation (behavioural, observation)

- Preference evaluation through choice experiments (comparison, experiment)

- Object based preference evaluation through computational methods

Methods that evaluate preferences through sensory acquisition (physiological) are interesting because they can measure implicit processing so they can acquire what humans can't or won't tell in surveys or interviews. They are per definition implicit. Interesting methods for the purpose of design decision could be the following: Electroencephalography (EEG), Electro Dermal Activity (EDA) and a combination of Electromyography (EMG) and EDA. Especially the combination of EDA and EMG can be interesting. Compared to other sensors, these are still quite cost-efficient and can capture emotions within the circumplex model (Valence-Arousal-Model) (Russell, 1980).

Methods of the group preference evaluation through questioning have the advantage that they are well-established to be evaluated statistically. Interesting methods for the purpose of design decision could be the following: Surveys with Likert scales, the semantic differential (Frey, 1993), the "Gefallensurteil" by Seeger (2005), "Nutzwertanalyse" (NWA) (Scoring model) (Zangemeister, 2014) and the AttrakDiff (a specific semantic differential) (Hassenzahl et al., 2003). An additional interesting method could be found in the Affect Misattribution Procedure (AMP) (Payne et al., 2005) this method measures preferences based on priming by briefly-displayed stimuli that appear shortly before preference to Chinese characters are evaluated and has already successfully been used in some studies (Wullenkord, 2017).

Choice based methods for preference evaluation which can be used in our approach are paired comparison (Thurstone, 1927), choice based conjoint (CBC) (Louviere, 1988), and the Analytical Hierarchy process (AHP) (Saaty, 2008). The cardinal scale which is integrated in the AHP doesn't seem to be that close to buying situations as ordinal decisions in paired comparisons and especially CBCs are. These two last-mentioned methods are therefore to be preferred.

Methods based on observation are interesting because they can measure implicit reactions (without sensors) Interesting methods for the purpose of design decision could be the following: eyes on screen (involvement), Eye Tracking, Facial Action Coding System (Ekman and Friesen, 1978), and especially the Implicit Association Test (IAT) (Greenwald et al., 1998).

Some attributes could get measured without customer's evaluation by Object based evaluation through computational methods. Interesting can be to measure Complexity on the basis of the stimuli picture (Landwehr, 2008), or to measure Symmetry, or even measure prototypicality via euclidic distance to a morph of multiple design stimuli (Landwehr, 2008) or evaluating Birkhoffs measure $(\mathrm{M}=\mathrm{O} / \mathrm{C})$ (Birkhoff, 1933) through computational methods. 


\subsection{Categorise methods based on the levels of perception and dimensions of design}

On the Basis of the insights of Section 6.1 all relevant methods shall be inserted in an overview. Figure 3 shows the methods ordered in groups based on their type of acquisition, categorised to dimensions and levels of perception (implicit and explicit). Additionally possible methods to measure emotions are presented; they are interesting to measure the situative emotional state as one of the moderating factors as described in Section 4.3.

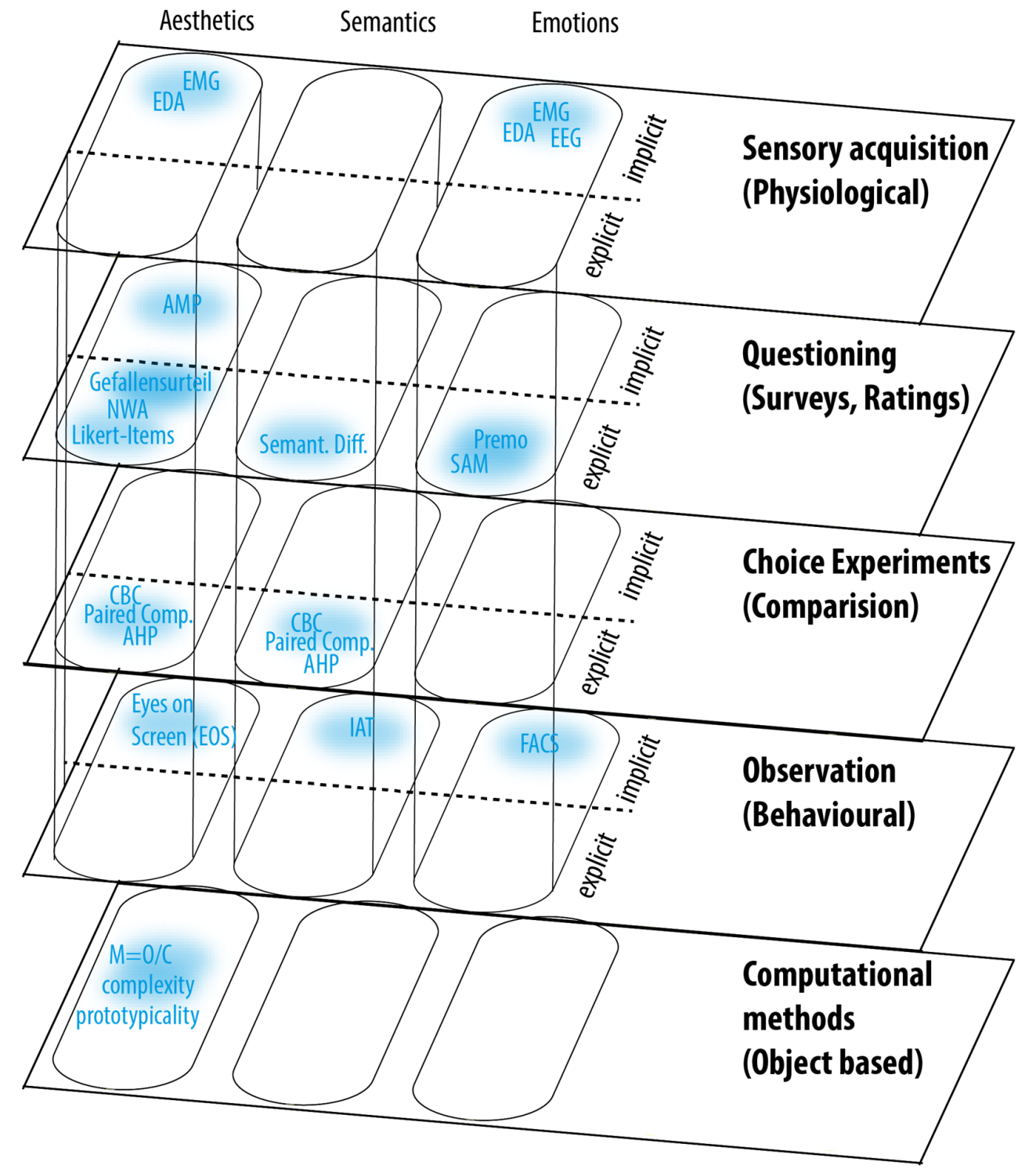

Figure 3. Evaluation methods integrated in the necessary dimensions which have to be considered in implicit and explicit processing

In this overview it can be seen that preference evaluation through sensory acquisition and through observation offer a wide range of methods to measure implicit processing whereas preference evaluation through questioning and through choice offer mainly methods to evaluate explicit processing. All methods are also listed in alphabetical order in Table 3. Furthermore, a distinction is made between methods already established in the field of design, as well as methods that can be adapted from other fields of science. 
Table 3. Methods to evaluate aesthetic preferences

\begin{tabular}{|c|c|c|c|c|c|c|c|c|c|}
\hline & Method & Author & 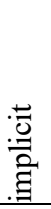 & 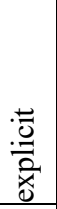 & 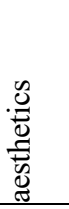 & 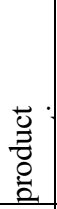 & .气̃̋ & 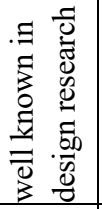 & 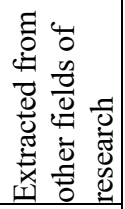 \\
\hline IAT & Implicit Association Test & Greenwald et al. (1998) & $\mathrm{x}$ & & & & & & $\mathrm{x}$ \\
\hline PS & Styles of Perception & Zeh (2010) & & $\mathrm{x}$ & & & & $(\mathrm{x})$ & \\
\hline SD & Semantic differential & Frey (1993) & & $\mathrm{x}$ & & $\mathrm{x}$ & & $\mathrm{x}$ & \\
\hline $\mathrm{AD}$ & Attrakdiff & Hassenzahl & & $\mathrm{x}$ & $\mathrm{x}$ & $\mathrm{x}$ & & $\mathrm{x}$ & \\
\hline SAM & Self-Assessment Manikin & Bradley, Lang (1994) & & $\mathrm{x}$ & & & $\mathrm{x}$ & & \\
\hline EDA & Electro Dermal Activity & Jung (1907) & $\mathrm{x}$ & & $\mathrm{x}$ & & $\mathrm{x}$ & & $\mathrm{x}$ \\
\hline EMG & Electromyography & Marey (1890) & $\mathrm{x}$ & & $(\mathrm{x})$ & & $\mathrm{x}$ & & $\mathrm{x}$ \\
\hline EEG & Electroencephalography & Berger (1929) & $\mathrm{x}$ & & $(\mathrm{x})$ & & $\mathrm{x}$ & & $\mathrm{x}$ \\
\hline AMP & $\begin{array}{l}\text { Affect Misattribution } \\
\text { Procedure }\end{array}$ & Payne et al. (2005) & $\mathrm{x}$ & & $\mathrm{x}$ & & & & $\mathrm{x}$ \\
\hline GU & Gefallensurteil & Seeger (2005) & & $\mathrm{x}$ & $\mathrm{x}$ & & & $\mathrm{x}$ & \\
\hline NWA & Nutzwertanalyse & Zangemeister (2014) & & $\mathrm{x}$ & $\mathrm{x}$ & $\mathrm{x}$ & & $(\mathrm{x})$ & \\
\hline LSS & Likert-Scale-Survey & Likert (1932) & & $\mathrm{x}$ & $\mathrm{x}$ & $\mathrm{x}$ & & $\mathrm{x}$ & \\
\hline $\mathrm{CBC}$ & Choice Based Conjoint & Louviere (1988) & & $\mathrm{x}$ & $\mathrm{x}$ & $\mathrm{x}$ & & & $\mathrm{x}$ \\
\hline AHP & Analytic Hierarchy Process & Saaty (2008) & & $\mathrm{x}$ & $\mathrm{x}$ & $\mathrm{x}$ & & & $\mathrm{x}$ \\
\hline $\mathrm{PC}$ & Paired Comparision & Thurstone (1927) & & $\mathrm{x}$ & $\mathrm{x}$ & $\mathrm{x}$ & & $\mathrm{x}$ & \\
\hline FACS & Facial action Coding System & $\begin{array}{l}\text { Ekman and Friesen } \\
(1978)\end{array}$ & $\mathrm{x}$ & & & & $\mathrm{x}$ & & $\mathrm{x}$ \\
\hline EOS & Eyes on screen & Yarbus (1967) & $\mathrm{x}$ & & $\mathrm{x}$ & & & & $\mathrm{x}$ \\
\hline $\mathrm{M}=\mathrm{O} / \mathrm{C}$ & Birkhoff's aesthetic measure & Birkhoff (1933) & & & $\mathrm{x}$ & & & $(\mathrm{x})$ & \\
\hline $\begin{array}{l}\text { Prototyp- } \\
\text { icality }\end{array}$ & $\begin{array}{l}\text { Measuring Prototypicality } \\
\text { based on morphing and } \\
\text { euclidic distance }\end{array}$ & Landwehr (2008) & & & $\mathrm{x}$ & & & $(\mathrm{x})$ & \\
\hline
\end{tabular}

\section{Selection of methods and attributes}

The selection of the methods should be done according to the exclusion principle. The big problem with methods within the group preference evaluation through sensory acquisition is that they need a laboratory environment. Therefore all these methods do not work in a decentralised way when applying the crowdsourcing approach. The problem with observations is similar; these usually do not work by crowdsourcing. One exception is the IAT, which is based on time measures and can be done online. Since these groups have to be ruled out for now (except the IAT) there are only two groups of methods left: The methods of choice and the methods of questioning. The methods of choice have the advantage that they are closer to consumer decisions e.g. buying decisions. Therefore, these will be in favour. In order to measure implicit aesthetic preferences no comparative method could be found, in this case the AMP will be used as a method out of the questioning group, which seems to be one of the only options to measure implicit aesthetic processing. The IAT seems to be ideal to evaluate bipolar attributes in the semantic dimensions shown in Section 3.4. The explicit semantic dimension with bipolar attributes can be measured by the semantic differential or the AttrakDiff. The main difference for these two is that out of the Attrakdiff there can be extracted a direct rating for Attractivity, Hedonic Quality and Pragmatic Quality whereas the semantic differential usually isn't used to extract ratings. The explicit processing of the aesthetic appreciation shall be measured by a choice based conjoint (CBC) or a paired comparison to get a better connection to the consumer behaviour e.g. buying situations. In addition, the buying intention and the "Word of mouth" (Schwemmle, 2016) should be evaluated as well with CBC or Paired 
Comparison. In Figure 4 all the selected methods and attributes can be found and it can be seen how the process of a "proof of concept" study for a design decision support tool could look like.

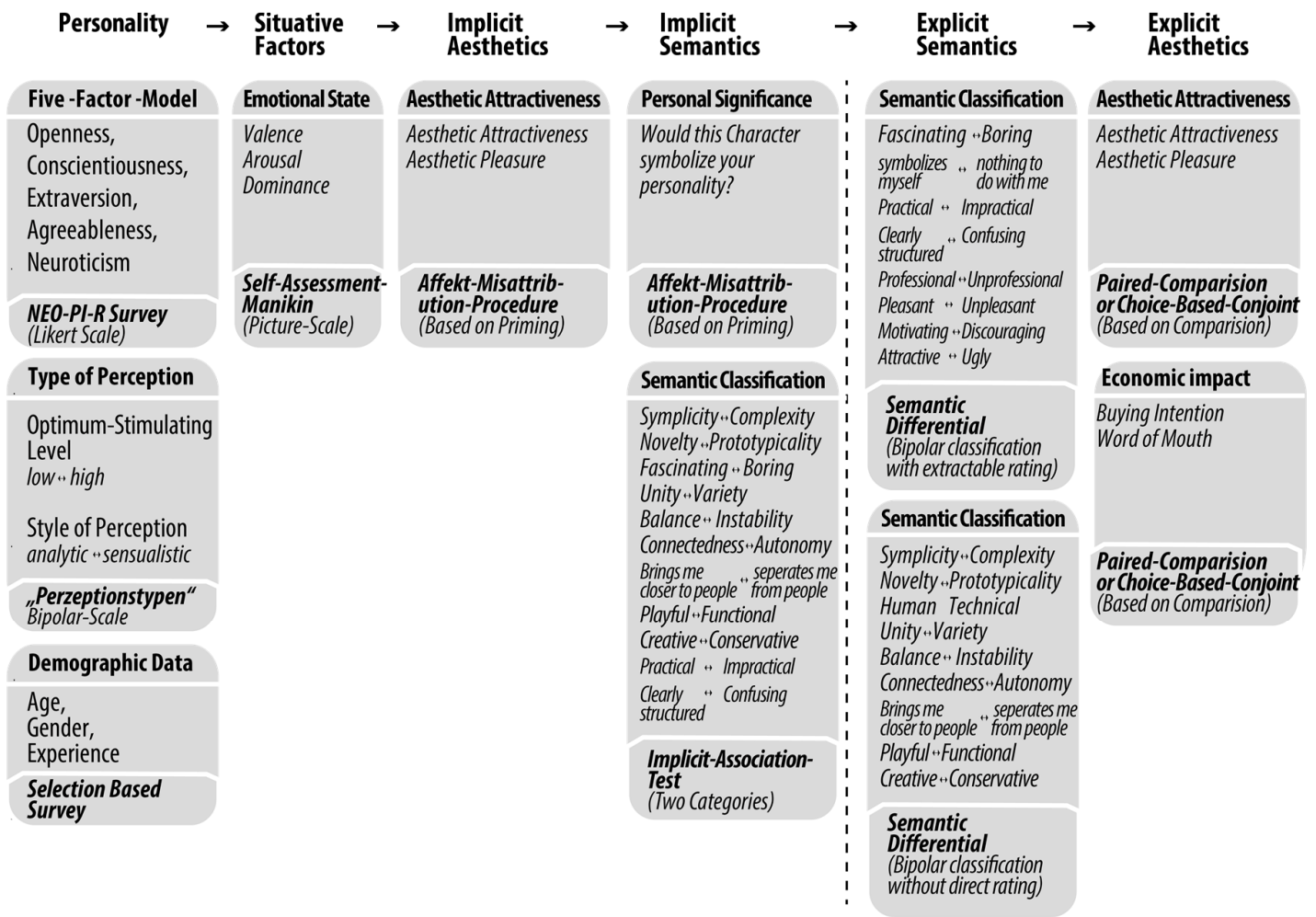

Figure 4. Selected methods and attributes arranged in the process of a planned study which will build the basis for the tool to support industrial design decisions

\section{Summary and outlook}

In this contribution, relevant theories and views on aesthetic evaluations and the involved processes of perception were analysed. An important finding from this is that a distinction must be made between implicit and explicit processing and therefore, it is necessary to define methods which measure explicitly and implicitly relevant attributes within the two main dimensions of Industrial Design (aesthetics and product semantics). Most product design scales are based on Likert scale acquisition and are therefore more targeted for evaluating explicit evaluating of design. Based on these insights in this article, a first collection of methods and associated attributes is generated. This approach has to be analysed in a first study and then the practicability to support design decisions has to be proven and to be optimised. The vision is to implement a web-based-tool for industrial designers (not only scientists) with which they can drag and drop their designs and to get a theoretically substantiated empirical result which design for which target group is preferred, so that finally industrial designer have better arguments in product development decisions.

\section{References}

Berger, H. (1929), "Über das Elektrenkephalogramm des Menschen”, Archiv für Psychiatrie und Nervenkrankheiten, Vol. 87 No. 1, pp. 527 - 570. https://doi.org/10.1007/BF01797193

Birkhoff, G.D. (1933), Aesthetic Measure, Harvard University Press, Cambridge. https://doi.org/10.4159/harvard.9780674734470

Blijlevens, J., Thurgood, C., Hekkert, P., Chen, L.-L., Leder, H. and Whitfield, T.W.A. (2017), "The Aesthetic Pleasure in Design Scale. The development of a scale to measure aesthetic pleasure for designed artifacts", Psychology of Aesthetics, Creativity, and the Arts, Vol. 11 No. 1, pp. 86 - 98. https://doi.org/10.1037/aca0000098 
Bloch, P.H. (1995), "Seeking the Ideal Form. Product Design and Consumer Response", Journal of Marketing, Vol. 59 No. 3, pp. 16 - 21. https://doi.org/10.2307/1252116

Burnap, A. (2016), Crowdsourcing for Engineering Design: Objective Evaluations and Subjective Preferences, $\mathrm{PhD}$ thesis, University of Michigan.

Chiu, C.-M., Liang, T.-P. and Turban, E. (2014), "What can crowdsourcing do for decision support?", Decision Support Systems, Vol. 65, pp. 40 - 49. https://doi.org/10.1016/j.dss.2014.05.010

Crilly, N., Moultrie, J. and Clarkson, P.J. (2004), "Seeing things: consumer response to the visual domain in product design", Design Studies, Vol. 25 No. 6, pp. 547 - 577. https://doi.org/10.1016/j.destud.2004.03.001

Digman, J.M. (1990), "Personality Structure: Emergence of the Five - Factor Model", Annual Review of Psychology, Vol. 41 No. 1, pp. 417 - 440. https://doi.org/10.1146/annurev.ps.41.020190.002221

Ekman, P. and Friesen, W.V. (1978), Facial action coding system, Palo Alto: Consulting Psychologist Press.

Fedrizzi, L. (2012), "Beauty and its perception: historical development of concepts, neuroaesthetics, and gender differences", Rendiconti Lincei, Vol. 23 No. 3, pp. 259 - 269. https://doi.org/10.1007/s12210-012-0177-1

Frey, B. (1993), Zur Bewertung von Anmutungsqualitäten, Beiträge zum Produkt - Marketing, Bd. 22, Förderges, Produkt - Marketing, Köln.

Graf, L.K.M. and Landwehr, J.R. (2015), “A dual - process perspective on fluency - based aesthetics: the pleasure - interest model of aesthetic liking”, Personality and social psychology review, Vol. 19 No. 4, pp. 395 - 410. https://doi.org/10.1177/1088868315574978

Greb, F., Elvers, P. and Fischinger, T. (2016), "Trends in Empirical Aesthetics", Empirical Studies of the Arts, Vol. 35 No. 1, pp. 3-26. https://doi.org/10.1177/0276237415625258

Greenwald, A.G., McGhee, D.E. and Schwartz, J.L.K. (1998), "Measuring individual differences in implicit cognition: The implicit association test", Journal of personality and social psychology, Vol. 74 No. 6, pp. 1464-1480. https://doi.org/10.1037/0022-3514.74.6.1464

Gros, J. (1987), Grundlagen einer Theorie der Produktsprache, Vol. 4, HfG, Hochsch. für Gestaltung, Fachbereich Produktgestaltung, Offenbach am Main

Hassenzahl, M., Burmester, M. and Koller, F. (2003), “AttrakDiff: Ein Fragebogen zur Messung wahrgenommener hedonischer und pragmatischer Qualität", In: Szwillus, G. (Ed.), Interaktion in Bewegung, Mensch \& Computer, Vol. 57, 1st ed., Teubner, Stuttgart, Leipzig, Wiesbaden, pp. 187 - 196. https://doi.org/10.1007/9783-322-80058-9 19

Herrmann, A. (1998), Produktmanagement, Vahlens Handbücher der Wirtschafts - und Sozialwissenschaften, Vahlen, München.

Howe, J. (2006), “The Rise of Crowdsourcing”, Wired Magazine, Vol. 14 No. 6, pp. 1 - 4, New York.

Ingarden, R. (1985), Selected papers in aesthetics, Philosophia resources library, Philosophia, Washington, DC

Jung, C.G. (1904 - 1907), Studies in Word Association, Routledge \& K. Paul, London.

Kohler, T.C. (2003), Wirkungen des Produktdesigns: Analyse und Messung am Beispiel Automobildesign, Gabler Edition Wissenschaft Forschungsgruppe Konsum und Verhalten, 1st ed., Dt.Univ.-Verl., Wiesbaden. https://doi.org/10.1007/978-3-322-81607-8

Krippendorff, K. (2006), The semantic turn: A new foundation for design, CRC/Taylor \& Francis, Boca Raton.

Landwehr, J.R. (2008), Ansätze zur Optimierung des Produktdesigns, PhD thesis, University of St. Gallen.

Leder, H., Belke, B., Oeberst, A. and Augustin, D. (2004), "A model of aesthetic appreciation and aesthetic judgments", British Journal of Psychology, Vol. 95 No. Pt 4, pp. 489 - 508 . https://doi.org/10.1348/0007126042369811

Likert, R. (1932), “A technique for the measurement of attitudes”, Archives of Psychology, Vol. 22 No. 140, pp. 5-55.

Little, G., Chilton, L.B., Goldman, M. and Miller, R.C. (2009), "TurKit: Human Computation Algorithms on Mechanical Turk", Proceeding UIST '10 Proceedings of the 23nd annual ACM symposium on User interface software and technology, New York, USA, October 03 - 06, 2010, ACM New York, New York, pp. 57-66.

Löbach, B. (1976), Industrial Design: Grundlagen der Industrieproduktgestaltung, K. Thiemig, München

Louviere, J.J. (1988), Analysing Decision Making: Metric conjoint analysis, Newbury Park: Sage Publications Inc. https://doi.org/10.4135/9781412983365

Merleau-Ponty, M. and Edie, J.M. (1971), The Primacy of Perception: And Other Essays on Phenomenological Psychology, the Philosophy of Art, History and Politics, Studies in Phenomenology \& Existential Philosophy, 2. paperback print, Northwestern Univ. Press, Evanston.

Metzger, W. (1966), "Figural-Wahrnehmung”, In: Metzger, W. (Ed.), Handbuch der Psychologie, Hogrefe Göttingen.

Norman, D.A. (2005), Emotional design: Why we love (or hate) everyday things, Basic Books, New York

Oehme, A. (2013), Ästhetisches Verständnis und ästhetische Werts chätzung von Automobildesign: Eine Frage der Expertise, $\mathrm{PhD}$ thesis, University Potsdam. 
Payne, B.K., Cheng, C.M., Govorun, O. and Stewart, B.D. (2005), “An inkblot for attitudes: affect misattribution as implicit measurement", Journal of Personality and Social Psychology, Vol. 89 No. 3, pp. 277 - 293 , https://doi.org/10.1037/0022-3514.89.3.277

Reber and Schwarz (1999), "Effects of perceptual fluency on judgments of truth", Consciousness and Cognition, Vol. 8 No. 3, pp. 338 - 342. https://doi.org/10.1006/ccog.1999.0386

Russell, J.A. (1980), “A circumplex model of affect”, Journal of Personality and Social Psychology, Vol. 39 No. 6, pp. 1161 - 1178. https://doi.org/10.1037/h0077714

Saaty, T.L. (2008), "Relative measurement and its generalization in decision making why pairwise comparisons are central in mathematics for the measurement of intangible factors the analytic hierarchy/network process", Revista de la Real Academia de Ciencias Exactas, Fisicas y Naturales. Serie A. Matematicas, Vol. 102 No. 2, pp. 251 - 318. https://doi.org/10.1007/BF03191825

Sabar, S. (2013), “What's a Gestalt?”, Gestalt Review, Vol 17. No. 1, pp. 6 - 34.

Schwemmle, M. (2016), Produktdesign, Springer Fachmedien Wiesbaden, Wiesbaden. https://doi.org/10.1007/978-3-658-12960-6

Seeger, H. (2005), Design technischer Produkte, Produktprogramme und - systeme: Industrial Design Engineering, 2nd ed., Springer - Verlag Berlin Heidelberg, Berlin, Heidelberg.

Steffen, D. (2000), Design als Produktsprache: Der "Offenbacher Ansatz" in Theorie und Praxis, Form Theorie, Verl. Form, Frankfurt am Main

Thurstone, L.L. (1927), "The Method of Paired Comparisons for Social Values", Journal of Abnormal and Social Psychology, Vol. 21 No. 4, pp. 384-400. https://doi.org/10.1037/h0065439

Tsai, C.I. and Thomas, M. (2011), "When does feeling of fluency matter?: how abstract and concrete thinking influence fluency effects", Psychological Science, Vol. 22 No. 3, pp. $348 \quad-\quad 354$. https://doi.org/10.1177/0956797611398494

Ulrich, K.T. (2011), Design: Creation of Artifacts in society, University of Pennsylvania,

Vajna, S. (2014), Integrated Design Engineering, Springer Berlin Heidelberg, Berlin, Heidelberg

Veryzer, R.W. (1995), "The Place of Product Design and Aesthetics in Consumer Research", Advances in Consumer Research, Vol. 22, pp. $641-645$.

Wirtz, M.A. (2014), Dorsch - Lexikon der Psychologie, 18th ed., Hogrefe Verlag, Bern.

Wullenkord, R. (2017), Messung und Veränderung von Einstellungen gegenüber Robotern - Untersuchung des Einflusses von im aginiertem Kontakt auf implizite und explizite Maße, PhD thesis, Universitätsbibliothek Bielefeld, Bielefeld.

Yamamoto, M. (1994), "The impact of product aesthetics on the evaluation of industrial products", Journal of Product Innovation Management, Vol. 11 No. 4, pp. 309 - 324. https://doi.org/10.1016/0737-6782(94)900868

Yanagisawa, H. and Fukuda, S. (2004), "Development of Interactive Industrial Design Support System Considering Customer's Evaluation”, JSME International Journal Series C, Vol. 47 No. 2, pp. 762 - 769. https://doi.org/10.1299/jsmec.47.762

Yarbus, AL. (1967) Eye Movements and Vision, New York: Plenum Press. https://doi.org/10.1007/978-1-48995379-7.

Zajonc, R.B. (1968), “Attitudinal effects of mere exposure”, Journal of personality and social psychology, Vol. 9 No. 2, Pt.2, pp. 1 - 27. https://doi.org/10.1037/h0025848

Zangemeister, C. (2014), Nutzwertanalyse in der Systemtechnik: Eine Methodik zur multidimensionalen Bewertung und Auswahl von Projektalternativen, 5th ed., Zangemeister \& Partner, Winnemark.

Zeh, N. (2010), Erfolgsfaktor Produktdesign, Beiträge zum Produkt - Marketing, Vol. 45, Förderges. Produkt Marketing, Köln

Martin Wiesner, M.A., Research Assistant

Otto von Guericke University Magdeburg, Institut für Maschinenkonstruktion

Universitätsplatz 2, 39106 Magdeburg, Germany

Email: martin.wiesner@ovgu.de 